\title{
The Effects of The Conjunctive Use of Compost Tea and Inorganic Fertilizers on Radish (Raphanus sativus) Nutrient Uptake and Soil Microorganisms
}

\author{
Sara E. Fouda" and A. S. Ali \\ *Soil Sci. Dept. and Agric. Microbiology Dept., Faculty of \\ Agriculture, Zagazig University, Egypt
}

\begin{abstract}
PPLICATION of organic amendments to soil is an important management strategy for enhancing soil fertility and microorganisms. A pot experiment was conducted under greenhouse conditions to investigate the effect of compost and compost tea(CT), mineral fertilization only complete $\left(\mathrm{N}_{100}\right)$ and half $\left(\mathrm{N}_{50}\right)$ recommended doses of nitrogen or combined with two kinds of compost tea (according to extract methods) molasses compost tea (CT1) and molasses compost tea+ ammonium sulphate (CT2) with three application ratios (v:v) (1:25, 1:50 and 1:75) on NPK uptake of leaf and root of radish (Raphanus sativus), soil nutrient status after harvest, and soil microbial populations. Application of CT1 showed that $\mathrm{N}$ uptake of radish leaf was about $30.1 \%$ higher than that of CT2. CT1 compost tea also increased P and K uptake by 12.6 and $51.5 \%$, respectively, compared with CT2 application. At the end of experiment, soil $\mathrm{N}, \mathrm{P}$ and $\mathrm{K}$ contents were greater in compost amended soil,whereas $\mathrm{N}$ uptake of radish leafand root showed only a significant positive correlation with soil $\mathrm{N}$ content in the CT2 $+\mathrm{N}$ treatments. The populations of the different microorganisms were greater in CT treatment, and increased with time as well. However, it was found that there was a significant negative correlation between leaf and root $\mathrm{N}$ uptake of radish and population of anaerobic $\mathrm{N}_{2}$ fixing bacteria in soil after harvest.
\end{abstract}

Keywords: Compost, Compost extract, Radish growth, Nutrient uptake, Soil microorganisms

The organic food industry is increasingly lucrative in Egypt. Organic farming involves additions of nutrients besides the non-synthetic materials such as mineral inorganic chemical fertilizers (Winter and Davis, 2006). Major benefits of organic farming are to produce safe food and to protect soil and agriculture production from pollution (Bourn and Prescott, 2002). Organic farming should optimize biological productivity of soil, and eliminate the use of synthetic products. Biodiversity of plant species, invertebrates, birds and other organisms should be higher in organic farms in comparison with conventional ones (Fuller et al., 2005).

Therefore, fertilizers such as farmyard manure, composts and other safe organic farm wastes should be applied (Carpenter-Boggs, 2005 and Warman,

*Corresponding author E-mail address: Sarafouda_2002@yahoo.com. 
2005). Many communities have composted their municipal organic solid wastes to use them as soil amendments(Otten, 2001).Quality of compostsvaries according to the nature of composted organic wastes or residues, as well as the type of composting procedure(He et al., 1995 and NOSB, 2004).Compost and compost extracts applied to the soil improve its quality by altering its chemical and physical properties, by increasing organic matter content, water holding capacity, overall diversity of microbes, by providing macro- and micro-nutrients essential for plant growth, and by suppressing diseases, which indirectly contribute to the increase in plant growth (Heather et al., 2006).

Compost tea made of leaf, coffee wastes and kitchen garbage could be useful sources of N, P and K for crops (Ebid et al., 2007). The efficiency of application of composts depends on their contents of nutrients and their rate of release (Cassman and Munns, 1980). Compost tea (water extract of solid organic compost) may contain hormones and microorganisms useful for plants and soil (Edris et al., 2003) because mineralization $\mathrm{N}$ of organic amendment is positively correlated with their contents of total N (Aulakh et al., 2000) as well as microbial N content (Antonopoulos, 1999). More research is needed to assess the nutrient supplying capacity of compost. Compost tea, incubated with various nutrients for microorganisms and in some cases inoculated with specific microbiota enhanced the microbial activity of compost extract (Bess, 2000). Compost tea contains high population of microbiota including Rhizobacteria, Trichoderma, and Pseudomonas spp., which enhances plant growth and crop yield (Sylvia, 2004). It also contains growth hormones and anti-pathonic chemicals such assiderophores tannins and phenols (Antonio et al., 2008), and vitamin C (Ha et al., 2008). Some microorganisms benefit plants through mechanisms such as nitrogen fixation and phosphate solubilization (Dubeikovsky et al., 1993).

According to Ingham (2005), sugar or molass, kelp extracts and pulverized rock materials including phosphate rock are used in organic farming. Addition of such material to the composts increased microbial population and growth (Naidu et al., 2010), and improved the $\mathrm{C} / \mathrm{N}$ ratio of the culture growing Chinese cabbage (Pant et al., 2009).

Therefore, the present study was conducted to assess the effects of compost teas made with two supplements (molasses and ammonium sulphate) on yield and leaf and root nutrient uptake of radish as well as the effect on soil microbial population.

\section{Material and Methods}

A greenhouse study on radish (Raphanus sativus) grown on a sand soil was conducted at the Faculty of Agriculture, Zagazig University, from November 2011 to January 2012. PVC pots contained $6.0 \mathrm{~kg}$ soil of each were used. The experiment was carried out in a randomized complete block design factorial with 3 factors (3 replicates) as follows: First factor; compost tea (CT), i.e. molass tea (CT1) and ammonium sulphate compost tea (CT2);second factor: compost preparation ratio: three ratios, i.e. 1:25 $\left(\mathrm{r}_{1}\right), 1: 50\left(\mathrm{r}_{2}\right)$, and 1:75 $\left(\mathrm{r}_{3}\right)$; and 
third factor, mineral $\mathrm{N}$ application: two doses half dose $\left(\mathrm{N}_{50}\right)$, and full dose $\left(\mathrm{N}_{100}\right)$. The full dose represents application of $210 \mathrm{~g} \mathrm{~N} \mathrm{~kg}^{-1}$ soil in the form of ammonium sulphate. Furthermore, there were three other treatments as follows: non-treated, mineral $\mathrm{N}$ treated supplied with the full dose of $\mathrm{N}$ and composttreated, supplied with $10 \mathrm{~g}$ compost $\mathrm{kg}^{-1}$ (about $24 \mathrm{Mg} \mathrm{ha}^{-1}$ considering the plough layer where $\mathrm{Mg}$ "megagram $=10^{6} \mathrm{~g}$ "). Application of compost tea was $300 \mathrm{ml} /$ pot , while application of compost was done before seeding and mixed thoroughly with soil; application of mineral $\mathrm{N}$ (as ammonium sulphate $210 \mathrm{~g} \mathrm{~N}$ $\mathrm{kg}^{-1}$ ) was done in two times one after 15 days of seeding and the second after 30 days of seeding. Watering was done so as to keep the moisture at about soil water-holding capacity. All treatments were supplied with $\mathrm{P}$ at the rate of $10 \mathrm{mg}$ $\mathrm{P} \mathrm{kg}^{-1}$ using calcium super phosphate and $10 \mathrm{mg} \mathrm{K} \mathrm{kg}^{-1}$ as potassium sulphate.

\section{Preparation of compost tea}

The solid compost made up of town-refuse compost, which was obtained from the Cairo Organic Fertilizers Company, Cairo, Egypt see (Table 2). Compost tea (water extract of compost) was prepared in Agric. Microbiology Department Laboratory, Faculty of Agriculture, Zagazig University, Egypt, according to the method of Ingham (2005). One kilogram fresh weight of compost was placed in a cotton bag, sealed them submerged for 4 days into $20 \mathrm{~L}$ of water in a plastic bucket. The tea compost was supplied with molass $\left(5 \mathrm{ml} \mathrm{L}^{-1}\right)$. Two types of compost tea were prepared. The first (CT1) was not supplemented with $\mathrm{N}$ while the second (CT2) was supplemented with mineral (ammonium sulphate $\mathrm{N}$ ) as $200 \mathrm{mg} \mathrm{N} \mathrm{L}^{-1}$. The reason for $\mathrm{N}$-addition was to enhance microbial activity and population. Fresh water was used for tea preparation.

Chemical composition of the compost and compost teas are shown in Table 1. The analysis was done according to standard methods described by Burnner and Wasmer (1978).

TABLE 1. Properties of compost and compost tea used in the study.

\begin{tabular}{|c|c|c|c|}
\hline Determinations & Compost & $\begin{array}{c}\text { Compost tea } \\
\left(\mathbf{C T}_{\mathbf{1}}\right)\end{array}$ & $\begin{array}{c}\text { Compost tea } \\
\left(\mathbf{C T}_{\mathbf{2}}\right)\end{array}$ \\
\hline $\mathrm{pH}$ & 7.5 & 7.2 & 7.1 \\
\hline $\mathrm{EC}\left(\mathrm{dSm}^{-1}\right)(1: 5)$ extract & 4.17 & 2.92 & 2.32 \\
\hline Total C, $\mathrm{g} \mathrm{kg}^{-1}$ (solid), $\mathrm{g} \mathrm{L}^{-1}$ (liquid) & 10.27 & 6.77 & 6.23 \\
\hline Total N, $\mathrm{g} \mathrm{kg}^{-1}$ (solid), $\mathrm{g} \mathrm{L}^{-1}$ (liquid) & 5.20 & 3.50 & 3.40 \\
\hline
\end{tabular}

Analysis of soil and plant materials

Soil for the experiment was collected from surface $(0-30 \mathrm{~cm})$ of an arable field near Zagazig City. Soil properties are given in Table 2. The main physical and chemical properties of the soil were determined according to the methods described by Klute (1986) and Page et al. (1982). 
The plant samples were collected separated into leaf and root and dried at $70^{\circ}$ digested using a mixture of concentrated sulfuric $\left(\mathrm{H}_{2} \mathrm{SO}_{4}\right)$ and perchloric $(\mathrm{HClO})$ acids (1:1). Nitrogen was determined by the micro Kheldahl method; $\mathrm{P}$ was determined in the acid mixture by the molybdate stannous chloride method and $\mathrm{K}$ was measured by the flame photometer. Fe, Mn and $\mathrm{Zn}$ were measured by the atomic absorption apparatus. These determinations were carried according to methods of Cottenie et al. (1982).

TABLE 2 Characteristics of soil used in the experiment

\begin{tabular}{|c|c|}
\hline Particle size distribution & Value \\
\hline Sand \% & 91.9 \\
\hline Silt\% & 6.0 \\
\hline Clay\% & 2.1 \\
\hline Textural class & Sand \\
\hline Organic matter $\left(\mathrm{g} \mathrm{kg}^{-1}\right)$ & 0.19 \\
\hline $\mathrm{CaCO}_{3}\left(\mathrm{~g} \mathrm{~kg}^{-1}\right)$ & 5.0 \\
\hline $\mathrm{EC} \mathrm{dSm}^{-1}$ (in paste extract) & 3.1 \\
\hline $\mathrm{pH}(1: 2.5)$ & 7.91 \\
\hline Total $\mathrm{N} \mathrm{g} \mathrm{kg}^{-1}$ & 3.4 \\
\hline Total $\mathrm{P} \mathrm{g} \mathrm{kg}^{-1}$ & 1.1 \\
\hline Total $\mathrm{K} \mathrm{g} \mathrm{kg}^{-1}$ & 0.6 \\
\hline Available $\mathrm{N} \mathrm{mg} \mathrm{kg}$ & 19.5 \\
\hline Available P mg kg-1 & 4.9 \\
\hline Available $\mathrm{K} \mathrm{mg} \mathrm{kg}^{-1}$ & 28.5 \\
\hline
\end{tabular}

Soil microbiological analysis

Microbial population was determined directly in soil samples as well as in compost and compost tea samples. Soil samples were collected at 0,4 and 8 weeks after seeding to determine total bacteria, aerobic $\mathrm{N}_{2}$-fixing bacteria, actinomycetes and fungi using plate count of most probable number (MPN) technique,bacteria was counted on nutrient agar after incubation at $30^{\circ} \mathrm{C}$ for 2 days (Difco, 1985). Enumeration of potential strict aerobe $\mathrm{N}_{2}$-fixing bacteria was done using the most probable number (MPN) technique (Abd-ElMalek, 1971) on Ashby modified medium incubated at $30^{\circ} \mathrm{C}$ for 7 days, while enumeration of aerobe $\mathrm{N}_{2}$-fixers was done as surface pellicle formation. Actinomycetes were enumerated on starch casein agar incubated at $28^{\circ} \mathrm{C}$ for 7 to 14 days (Conn and Leci, 1998), while fungi were enumerated on Martin's streptomycin rose bengal agar, incubated at $25^{\circ} \mathrm{C}$ for $3-5$ days (Atlas, 2005).All

Egypt. J. Soil Sci. 56, No. 2 (2016) 
enumerations were in three replicates. The microbial populations in microbeenriched compost and compost tea used in the experiment are shown in Table 3.

TABLE 3. Microbial populations in microbe-enriched compost and compost tea used

in the experiment
\begin{tabular}{|l|c|c|c|}
\hline \multicolumn{1}{|c}{ Microorganisms } & $\begin{array}{c}\text { Compost } \\
(\log 10 \text { CFU/g) }\end{array}$ & $\begin{array}{c}\text { Compost tea } \\
\left(\mathbf{C T}_{\mathbf{1}}\right) \\
(\log 10 \text { CFU/ml })\end{array}$ & $\begin{array}{c}\text { Compost tea } \\
\left(\mathbf{T C} \mathbf{~}_{\mathbf{2}}\right) \\
(\log 10 \mathbf{C F U} / \mathbf{m l})\end{array}$ \\
\hline Bacteria & 8.32 & 7.86 & 7.65 \\
\hline Aerobic $\mathrm{N}_{2}$ fixing bacteria & 1.23 & 3.34 & 1.15 \\
\hline Actinomycetes & 6.54 & 5.72 & 5.59 \\
\hline Fungi & 4.41 & 2.50 & 2.78 \\
\hline
\end{tabular}

Plant growth and yield

\section{Results and Discussion}

The total number of leaf per plant was higher in the treatments of compost, compost extracts and mineral nitrogen singly or in any combination. The increases ranged from $42.9 \%$ to $100 \%$ (Table 4). Compost tea was reported to enhance the growth of melons (Bernal-Vicente et al., 2008) and of okra (Siddiqui et al., 2008).Plants which received mineral $\mathrm{N}$ gave the highest number of leaf amounting to $100 \%$. The $\mathrm{CT}_{50}$ was more positive effect than the other two ratios. Compost treatment produced the highest fresh weight leaf, followed by $\mathrm{CT} 1+\mathrm{N}_{50}$. The lowest fresh weight leaf was recorded with $\mathrm{CT} 2+\mathrm{N}_{100}$ treatments. However, $\mathrm{CT}_{50}$ gave the highest yield and number of leaf over the other ratios. Similar trends were observed with dry weight of leaf and root (Table 5). Sifola and Barbieri (2006) reported that organic N, as well as organic-inorganic $\mathrm{N}$ combinations increased plant growth.

\section{Leaf nutrient uptake}

Lowest $\mathrm{N}$ uptake was in plants not treated with any fertilizer. Highest uptake was in plants receiving $\mathrm{CT} 1_{50}$ which gave $62.8 \%$ increase. The CT1 gave an average of $30.1 \%$ over that of CT2 (Table 6). This may indicate that $\mathrm{N}$ in the CT2 was subjected to greater immobilization in the soil. Elsherbeny et al. (2012) reported that the wide ratio of compost: water increased $\mathrm{N}$ uptake in turnip plant. Also, the lowest uptake of $\mathrm{P}$ and $\mathrm{K}$ were given by the non-treated plants. But, the highest uptake was given by the $\mathrm{CT}_{125}$ with full $\mathrm{N}$-dose which showed $47.6 \%$ increase in $\mathrm{P}$ uptake and by the $\mathrm{CT}_{50}$ with $\mathrm{N}_{100}$ which showed $75.4 \%$ increase in $\mathrm{K}$ uptake (Table 6). In addition, the CT1 compost tea gave greater uptake of $\mathrm{P}$ and $\mathrm{K}$ over the CT2 amounting to averages of 12.6 and $51.5 \%$ for $\mathrm{P}$ and $\mathrm{K}$ uptake respectively. Elsherbeny et al. (2012) reported a decrease in $\mathrm{P}$ content in plant treated by inorganic fertilizer compared with plant $\mathrm{P}$ content in plant treated by humic and compost tea. Moreover, leaf $\mathrm{P}$ and $\mathrm{K}$ uptake affected by increasing compost tea ratios. Application of compost tea with or without $\mathrm{N}$ dosage increased leaf $\mathrm{N}$ and $\mathrm{K}$ uptake. 
TABLE 4. The influence of different organic wastes and inorganic fertilizer on leaf number plant $^{-1}$ and leaf and root fresh weight of radish

\begin{tabular}{|c|c|c|c|c|c|c|c|c|c|c|}
\hline \multirow{3}{*}{$\begin{array}{l}\text { Compost } \\
\text { (CT) }\end{array}$} & \multirow{3}{*}{$\begin{array}{l}\text { Compost } \\
\text { ratio } \\
\text { (r) }\end{array}$} & \multicolumn{3}{|c|}{$\begin{array}{c}\text { Number of leaf } \\
\text { plant }^{-1}\end{array}$} & \multicolumn{3}{|c|}{$\begin{array}{l}\text { Leaf fresh weight } \\
(\mathrm{g})\end{array}$} & \multicolumn{3}{|c|}{$\begin{array}{l}\text { Root fresh weight } \\
\text { (g) }\end{array}$} \\
\hline & & \multicolumn{3}{|c|}{$\mathbf{N}$ support (N) } & \multicolumn{3}{|c|}{$\mathbf{N}$ support (N) } & \multicolumn{3}{|c|}{$\mathbf{N}$ support (N) } \\
\hline & & $\mathrm{N}_{50}$ & $\mathrm{~N}_{100}$ & Mean & $\mathrm{N}_{50}$ & $\mathrm{~N}_{100}$ & Mean & $\mathrm{N}_{50}$ & $\mathrm{~N}_{100}$ & Mean \\
\hline \multirow{3}{*}{ CT1 } & $\mathrm{CT} 1_{25}$ & 10.67 & 11.67 & 11.17 & 19.37 & 17.67 & 18.52 & 16.04 & 30.93 & 23.49 \\
\hline & $\mathrm{CT} 1_{50}$ & 13.00 & 13.00 & 13.00 & 22.26 & 19.33 & 20.80 & 29.43 & 38.32 & 33.87 \\
\hline & $\mathrm{CT}_{75}$ & 12.00 & 11.67 & 11.83 & 23.30 & 14.37 & 18.83 & 32.42 & 28.37 & 30.40 \\
\hline \multicolumn{2}{|c|}{ Mean } & 11.89 & 12.11 & & 21.64 & 17.12 & & 25.96 & 32.54 & \\
\hline \multirow{3}{*}{$\mathrm{CT} 2$} & $\mathrm{CT} 2_{25}$ & 11.67 & 10.67 & 11.17 & 19.23 & 12.80 & 16.02 & 24.41 & 17.47 & 20.94 \\
\hline & $\mathrm{CT} 2_{50}$ & 11.33 & 10.00 & 10.67 & 17.47 & 16.20 & 16.83 & 30.27 & 23.05 & 26.66 \\
\hline & $\mathrm{CT} 2_{75}$ & 11.00 & 10.67 & 10.83 & 14.00 & 20.77 & 17.38 & 21.80 & 41.98 & 31.89 \\
\hline \multicolumn{2}{|c|}{ Mean } & 11.33 & 10.44 & & 16.90 & 16.59 & & 25.49 & 27.50 & \\
\hline \multicolumn{2}{|c|}{ General mean } & 11.61 & 11.28 & & 19.27 & 16.86 & & 25.73 & 30.02 & \\
\hline \multicolumn{11}{|c|}{ Means of ratios } \\
\hline \multicolumn{2}{|c|}{$\mathrm{CT}_{25}$} & 11.17 & 11.17 & 11.17 & 19.30 & 15.23 & 17.27 & 20.23 & 24.20 & 22.22 \\
\hline \multicolumn{2}{|c|}{$\mathrm{CT}_{50}$} & 12.17 & 11.50 & 11.83 & 19.86 & 17.77 & 18.81 & 29.85 & 30.69 & 30.27 \\
\hline \multicolumn{2}{|c|}{$\mathrm{CT}_{75}$} & 11.50 & 11.17 & 11.33 & 18.65 & 17.57 & 18.11 & 27.11 & 35.18 & 31.14 \\
\hline \multicolumn{2}{|c|}{ Non-treated } & \multicolumn{3}{|c|}{9.00} & \multicolumn{3}{|c|}{8.67} & \multicolumn{3}{|c|}{9.17} \\
\hline \multicolumn{2}{|c|}{ Mineral-N treated } & \multicolumn{3}{|c|}{14.00} & \multicolumn{3}{|c|}{20.77} & \multicolumn{3}{|c|}{31.17} \\
\hline \multicolumn{2}{|c|}{ Compost } & \multicolumn{3}{|c|}{11.33} & \multicolumn{3}{|c|}{24.67} & \multicolumn{3}{|c|}{27.73} \\
\hline \multicolumn{11}{|c|}{ LSD 0.05} \\
\hline & & & NS & & & NS & & & 0.34 & \\
\hline & & & NS & & & 1.03 & & & 0.70 & \\
\hline & & & NS & & & 0.72 & & & 0.75 & \\
\hline & & & NS & & & 1.46 & & & 0.99 & \\
\hline $\mathrm{C}^{\mathrm{Z}}$ & & & NS & & & 1.02 & & & 1.07 & \\
\hline & & & NS & & & 1.34 & & & 1.40 & \\
\hline $\mathrm{C}^{* 1}$ & & & NS & & & 1.45 & & & 1.51 & \\
\hline
\end{tabular}

NS: non-significant.

Egypt. J. Soil Sci. 56, No. 2 (2016) 
THE EFFECTS OF THE CONJUNCTIVE USE OF COMPOST TEA ...

TABLE 5. The influence of different organic wastes and inorganic fertilizer on leaf and root dry weight of radish

\begin{tabular}{|c|c|c|c|c|c|c|c|}
\hline \multirow{3}{*}{$\begin{array}{l}\text { Compost } \\
\text { (CT) }\end{array}$} & \multirow{3}{*}{$\begin{array}{l}\text { Compost } \\
\text { ratio }(\mathbf{r})\end{array}$} & \multirow{2}{*}{\multicolumn{3}{|c|}{$\begin{array}{c}\text { Leaf dry weight (g) } \\
\text { N support }(\mathbf{N}) \\
\end{array}$}} & \multirow{2}{*}{\multicolumn{3}{|c|}{$\begin{array}{l}\text { Root dry weight (g) } \\
\text { N support }(\mathbf{N})\end{array}$}} \\
\hline & & & & & & & \\
\hline & & $\mathrm{N}_{50}$ & $\mathrm{~N}_{100}$ & Mean & $\mathrm{N}_{50}$ & $\mathrm{~N}_{100}$ & Mean \\
\hline \multirow{3}{*}{ CT1 } & $\mathrm{CT}_{25}$ & 1.68 & 2.64 & 2.16 & 1.96 & 3.65 & 1.96 \\
\hline & $\mathrm{CT}_{50}$ & 2.12 & 2.39 & 2.26 & 1.72 & 3.19 & 1.72 \\
\hline & $\mathrm{CT} 1_{75}$ & 1.69 & 3.46 & 2.58 & 1.97 & 2.50 & 1.97 \\
\hline \multicolumn{2}{|c|}{ Mean } & 1.83 & 2.83 & & 3.11 & 1.88 & \\
\hline \multirow{3}{*}{$\mathrm{CT} 2$} & $\mathrm{CT} 2_{25}$ & 1.69 & 1.41 & 1.55 & 1.61 & 1.92 & 1.77 \\
\hline & $\mathrm{CT} 2_{50}$ & 1.93 & 1.34 & 1.63 & 1.98 & 1.84 & 1.91 \\
\hline & $\mathrm{CT} 2_{75}$ & 1.46 & 2.27 & 1.87 & 2.45 & 1.97 & 2.21 \\
\hline \multicolumn{2}{|c|}{ Mean } & 1.69 & 1.67 & & 2.01 & 1.91 & \\
\hline \multicolumn{2}{|c|}{ General mean } & 1.76 & 2.25 & & 2.56 & 1.90 & \\
\hline \multicolumn{8}{|c|}{ Means of ratios } \\
\hline \multicolumn{2}{|c|}{$\mathrm{CT}_{25}$} & 1.69 & 2.02 & \begin{tabular}{|c|}
1.8 \\
6
\end{tabular} & 2.63 & 1.94 & $\begin{array}{c}2.2 \\
9 \\
\end{array}$ \\
\hline \multicolumn{2}{|c|}{$\mathrm{CT}_{50}$} & 2.03 & 1.87 & $\begin{array}{c}1.9 \\
5\end{array}$ & 2.59 & 1.78 & $\begin{array}{c}2.1 \\
8\end{array}$ \\
\hline \multicolumn{2}{|c|}{$\mathrm{CT}_{75}$} & 1.58 & 2.87 & $\begin{array}{c}2.2 \\
2 \\
\end{array}$ & 2.47 & 1.97 & $\begin{array}{c}2.2 \\
2 \\
\end{array}$ \\
\hline \multicolumn{2}{|c|}{ Non-treated } & \multicolumn{3}{|c|}{0.49} & \multicolumn{3}{|c|}{0.86} \\
\hline \multicolumn{2}{|c|}{ Mineral-N } & \multicolumn{3}{|c|}{2.47} & \multicolumn{3}{|c|}{3.57} \\
\hline \multicolumn{2}{|c|}{ Compost } & \multicolumn{3}{|c|}{1.63} & \multicolumn{3}{|c|}{2.40} \\
\hline \multicolumn{8}{|c|}{ LSD 0.05} \\
\hline \multicolumn{2}{|c|}{$\mathrm{C}$} & \multicolumn{3}{|c|}{ NS } & \multicolumn{3}{|c|}{0.19} \\
\hline \multicolumn{2}{|c|}{$\mathrm{N}$} & \multicolumn{3}{|c|}{0.20} & \multicolumn{3}{|c|}{0.21} \\
\hline \multicolumn{2}{|c|}{$\mathrm{R}$} & \multicolumn{3}{|c|}{0.19} & \multicolumn{3}{|c|}{0.18} \\
\hline & & & 0.28 & & & 0.30 & \\
\hline & & & 0.34 & & & 0.26 & \\
\hline & & & NS & & & 0.34 & \\
\hline & $* \mathrm{R}$ & & 0.49 & & & 0.37 & \\
\hline
\end{tabular}

*NS:non-significant

Considering the effect of treatments on plant chemical composition, a small increase was observed in $\mathrm{N}, \mathrm{P}$ and $\mathrm{K}$ uptake in plants treated with the combined application of $\mathrm{CT}$ and $\mathrm{N}_{50}$. It has been reported that compost, compost tea or biofertilizer increased plant macronutrient content, and this was related to a positive effect on increasing the root surface area unit of soil volume, water use efficiency and photosynthetic activity, which directly affect physiological processes (Siddiqui et al., 2011). These suggestions are supported by this study, which illustrates the higher levels of nutrients and beneficial microorganisms in compost tea. 


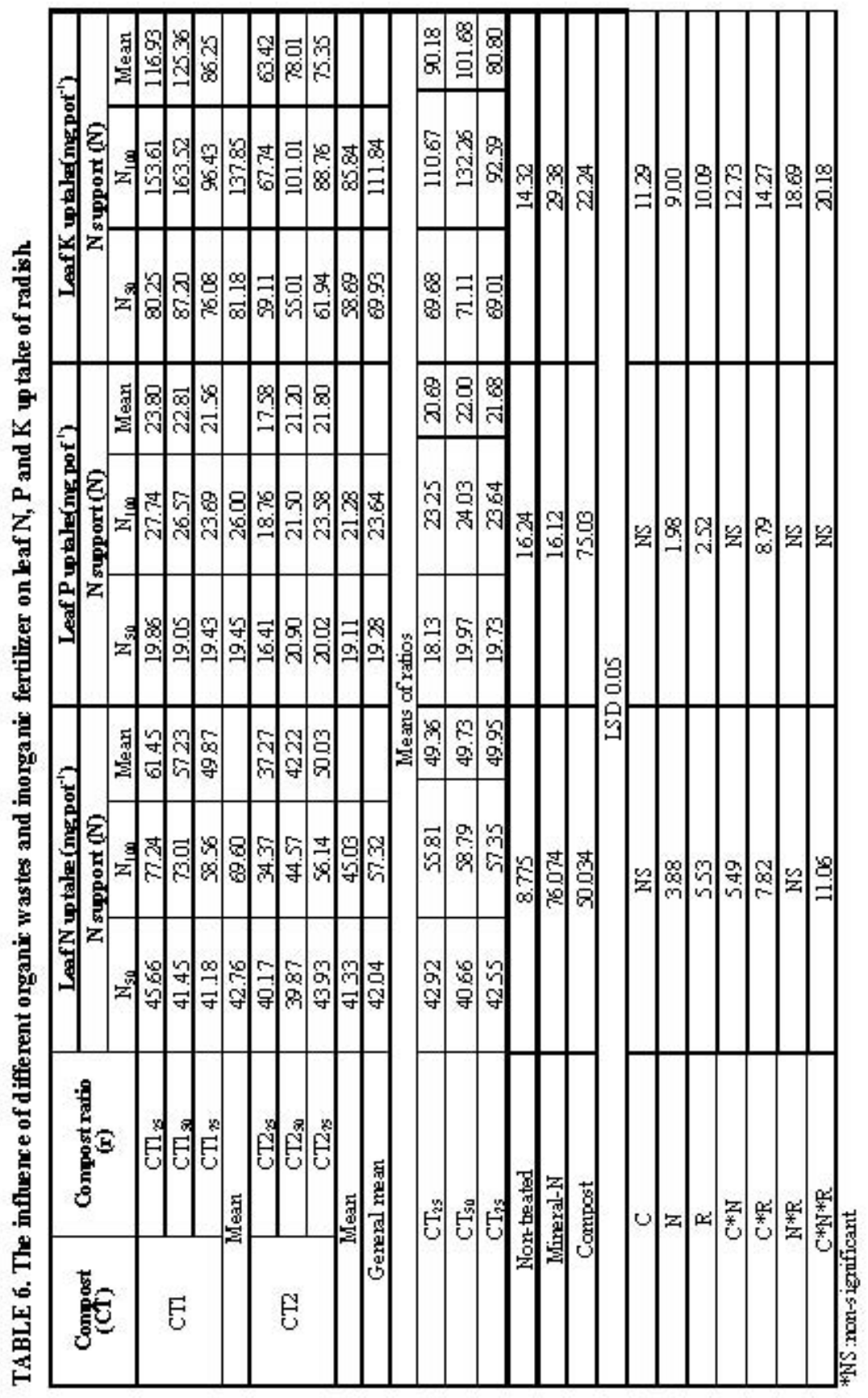

Egypt. J. Soil Sci. 56, No. 2 (2016) 


\section{Root nutrient uptake}

Uptake of nutrient in root was lower than in leaf (Table 7). The lowest $\mathrm{N}$ uptake in plants was in untreated ones. While, the highest uptake was in plants of $\mathrm{CT}_{75}$ whichgiving $97 \%$ over the untreated plants, CT1 gave an average $70 \%$ over that of CT2.Root $\mathrm{N}$ uptake was higher in $\mathrm{CT} 1+\mathrm{N}_{100}$ compared with those obtained by CT2 $+\mathrm{N}_{100}$. On the other hand, the application CT2 $+\mathrm{N}_{50}$ gave higher $\mathrm{N}$; P and $\mathrm{K}$ uptake compared with CT2 $+\mathrm{N}_{100}$. These results are in disagreement with those found by Siddiqui et al. (2011) who reported that the combination application of compost tea and $\mathrm{N}_{50}$ of the recommended dose increased $\mathrm{N}, \mathrm{P}$ and $\mathrm{K}$ uptake by the plant compared to the combination of compost tea and $\mathrm{N}_{100}$.

Treatment receiving $\mathrm{N}$ gave lower $\mathrm{P}$ and $\mathrm{K}$ uptake compared to those obtained from compost tea and compost treatments. The ratios of compost teas did not affect $\mathrm{N}$ uptake. Hirzel et al. (2012) reported that adding compost tea to the soil without fertilization did not affect ryegrass dry matter but it had a positive effect on the treatments with solid composts. Compost tea sources and $\mathrm{N}$ dosages individually increased $\mathrm{N}, \mathrm{P}$ and $\mathrm{K}$ uptake.

\section{Soil nutrient status after the experiment}

At the end of the experiment, there were greater $\mathrm{N}, \mathrm{P}$ and $\mathrm{K}$ contents in soil receiving compost of compost tea (Table 8). The contents increased due to increasing compost tea ratios. Siddiqui et al. (2011) found that application of compost tea increased $\mathrm{N}, \mathrm{P}$ and $\mathrm{K}$ soil content compared with inorganic fertilizer alone, and the increase depended on compost tea ratios.

Favorable effect of compost tea on plant growth may be due to enhancement physical, chemical and biological properties of soil. It has been reported that added organic materials, together with microbial activity, improved soil health and fertility (Loveland and Webb, 2003). These changes often result in improved plant growth (Antolan et al., 2005). Soil N content increased with compost treatments alone than with compost tea with inorganic fertilizer.

Positive effects are indications of equilibrium of nutrients and water in plant root zone (Aziz et al., 2007) as well as vital hormones and enzymes. Applications of $\mathrm{CT} 1+\mathrm{N}_{100}$ as well as $\mathrm{CT} 2+\mathrm{N}_{100}$ raised soil $\mathrm{N}$ content. Similar trend were found with soil $\mathrm{P}$ and $\mathrm{K}$ after the experiment. Compost tea provided significantly greater amounts of $\mathrm{P}$ to the soil than same source of compost, these results agree with those of Hargreaves et al. (2008).

Compost tea application along with mineral in half dose increased NPK in soil (Table 8). Continued use of compost tea supplement increased soil fertility as well as N, P and K content of the soil (Siddiqui et al., 2011). 


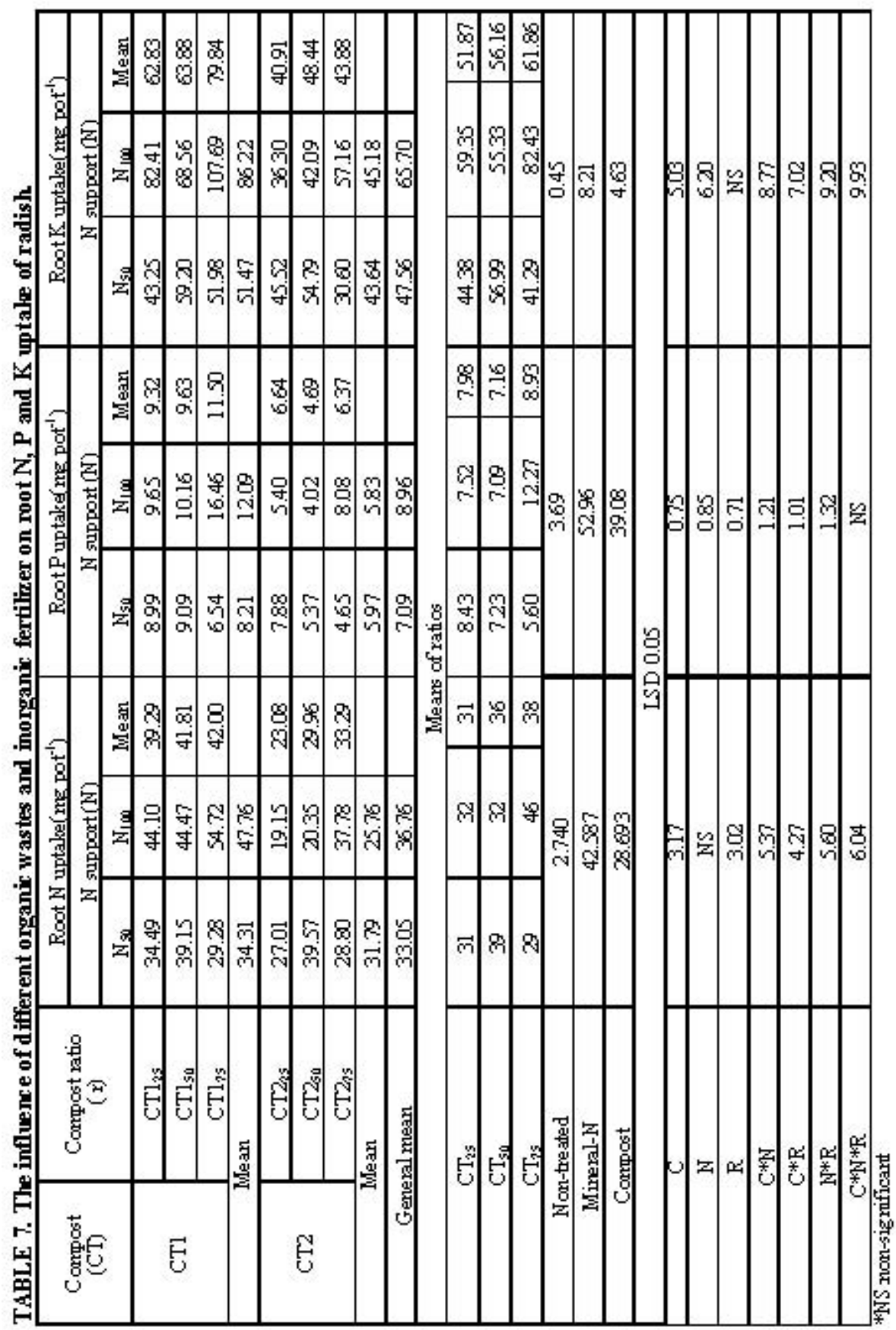

Egypt. J. Soil Sci. 56, No. 2 (2016) 
THE EFFECTS OF THE CONJUNCTIVE USE OF COMPOST TEA ...

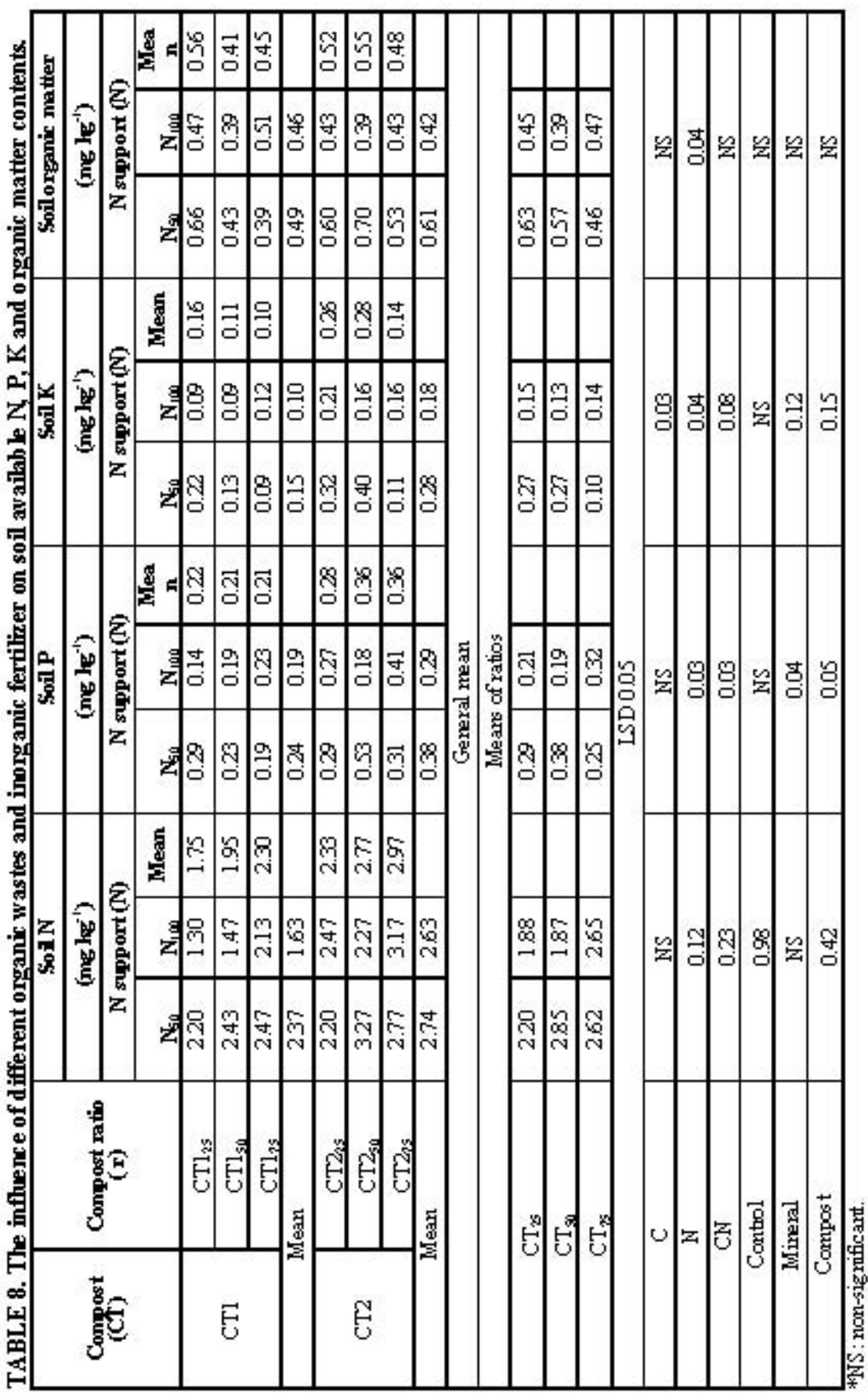

Egypt. J. Soil Sci. 56, No. 2 (2016) 
Microbial Population in Soil

Soil samples were collected at the beginning of planting, middle age of plants (after 4 weeks of planting) and after8 weeks of planting to determine total count of bacteria, aerobic $\mathrm{N}_{2}$-fixing bacteria, actinomycetes and fungi. The results presented in Fig. 1 showed that at the beginning of cultivation, all treatments recorded lower total counts of bacteria compared with counts at 4 or 8 weeks later except full dose of $\mathrm{N}$. The non-treated treatment showed the lowest bacterial counts compared with the other treatments.

After 8 weeks of cultivation, bacterial counts were higher compared with those other times. Bacterial counts were higher in the soil treated with compost and compost tea. Carbon energy sources leaked from root stimulates the number of heterotrophic bacteria and free-living $\mathrm{N}_{2}$-fixers the root zone of soil (Herman et al., 1993), particularly where, organic matter is introduced to soil.This can be explained by the increased nutrition supplement due to the compost and compost tea (Heather et al., 2006).

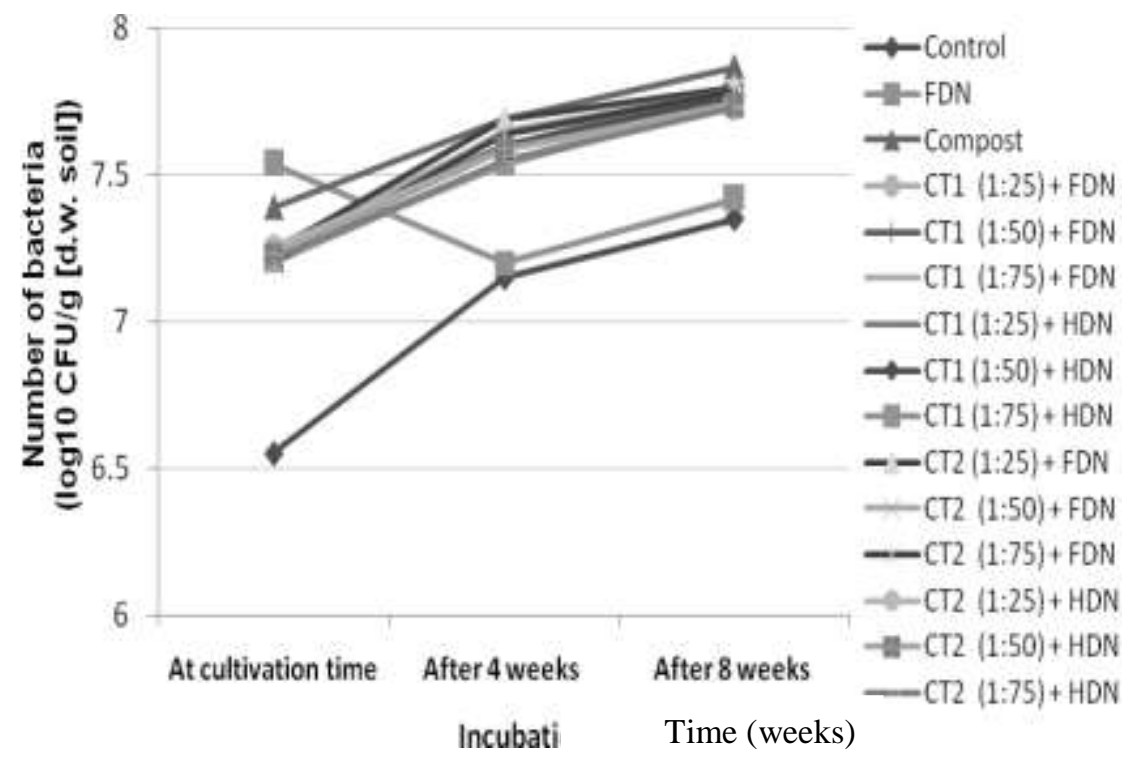

Fig. 1. Changes in total count of bacteria in the soil of cultivation, during the time course of the experiment.

The results presented in Fig. 2 showed counts of aerobic $\mathrm{N}_{2}$-fixing bacteria in the soil as affected by different treatments of compost and compost tea combined with two $\mathrm{N}$ doses. There was an increase due to the various $\mathrm{N}$ treatments that contained compost only compared with treatments containing $\mathrm{N}$ only. Treatments containing high dose of $\mathrm{N}$, exhibited a significant decrease in aerobic $\mathrm{N}_{2}$-fixing bacterial count after 4 weeks of cultivation compared with counts after 8 weeks. Also, soils with high contents of $\mathrm{N}$ had the lowest counts of $\mathrm{N}_{2}$ fixing bacteria (Streeter, 1988 and Herman et al., 1993).

Egypt. J. Soil Sci. 56, No. 2 (2016) 

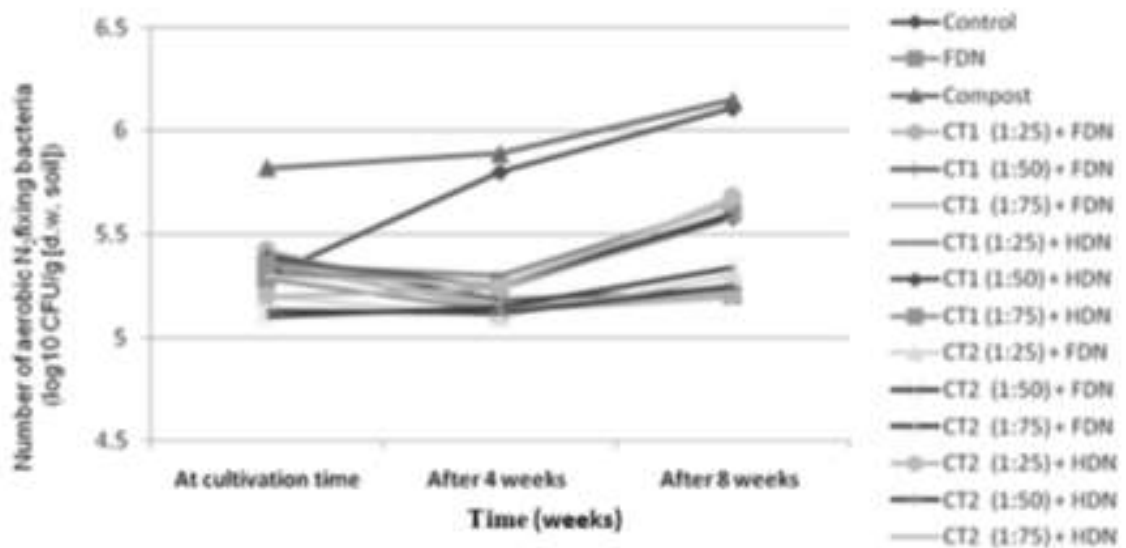

Fig. 2. Changes in total count of aerobic $\mathrm{N}_{2}$-fixing bacteria in the soil of cultivation, during the time course of the experiment.

A high great increase in actinomycetes counts was observed in all treatments containing compost or compost tea after 4 and 8 weeks of planting compared with the compost-free treatments (Fig. 3). Actinomycetes in a microbial community increase in number in late stages after other microorganisms consume the easily degradable compounds; then after actinomycetes start to utilize more stable compounds (Gagnon et al., 2001). However, total counts of actinomycetes were markedly increased compared with most counts of the earlier periods. This could be attributed to antibiotic agents that might be produced by actinomycetes which inhibit activity of other microorganisms and allow for competitor in favor of the actinomycetes (Craft and Nelson, 1996).

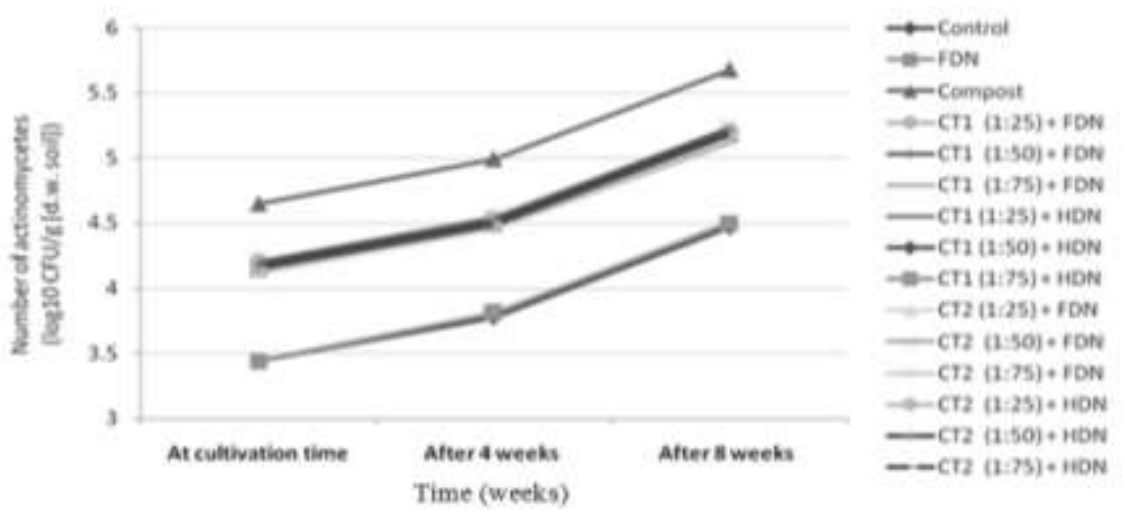

Fig. 3. Changes in total count of actinomycetesin the soil of cultivation, during the time course of the experiment.

Total fungi counts decreased in most compost treatments (Fig. 4) after 8 weeks after planting compared with 4 weeks period. This might be attributed to

Egypt. J. Soil Sci. 56, No. 2 (2016) 
competition for nutrients, competition for penetration sites (Takenaka et al., 2008); hyperparasitism (Danon et al., 2007) and induction of plant systematic resistance (Kavroulakis et al., 2005). The collective data obtained here are in compatibility with Nelson \& Boehm (2002) and Hegazy et al. (2013).

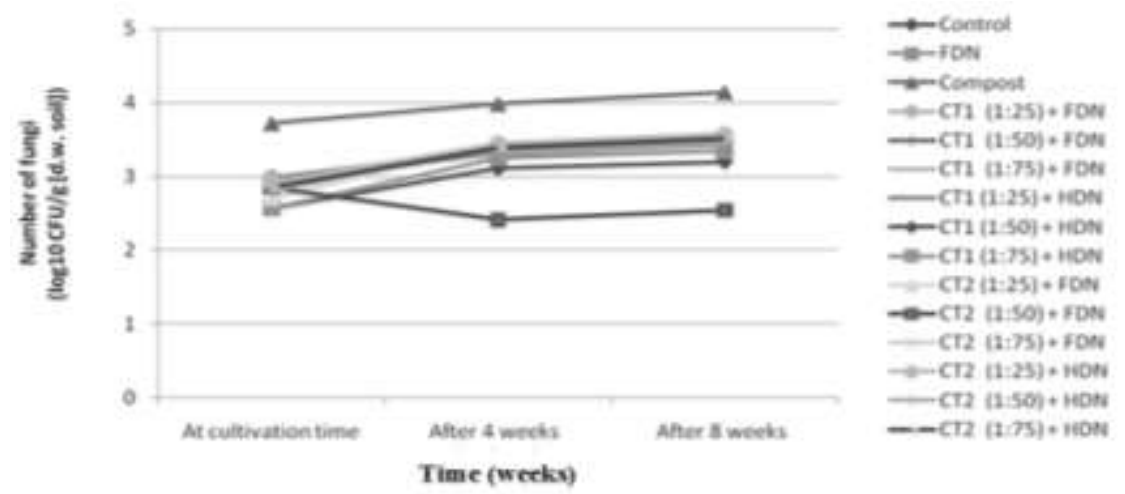

Fig. 4. Changes in total count of fungi in the soil of cultivation, during the time course of the experiment.

Correlations between radish plant $N$ uptake and soil total $N$ after harvest

After harvest, $\mathrm{N}$ uptake in radish leaf and root showed a significant positive correlation with soil total $\mathrm{N}$ content (Fig. 5) with $\mathrm{r}=0.97 * *$ and $\mathrm{r}=0.54 * *$ respectively, with the CT1 $+\mathrm{N}$. Such correlations are similar with $(\mathrm{CT} 2+\mathrm{N}$ treatment).These results agree with those reported by Martynuik et al. (2002), Schröder et al. (2005) and Angers et al. (2010) as well as those by Daugaard (2001) and Ebid et al. (2007) who reported that nutrient content decreased with increased soil $\mathrm{N}$. Observations in this study show that amount of $\mathrm{N}$ released was independent of the total $\mathrm{N}$ of compost tea. A significant positive correlation was obtained between soil organic matter and soil $\mathrm{N}$ with correlation coefficient of $\mathrm{r}=0.69^{* *}$ (data not shown) This indicates that availability of $\mathrm{N}$ in the soil depends on soil organic matter content.
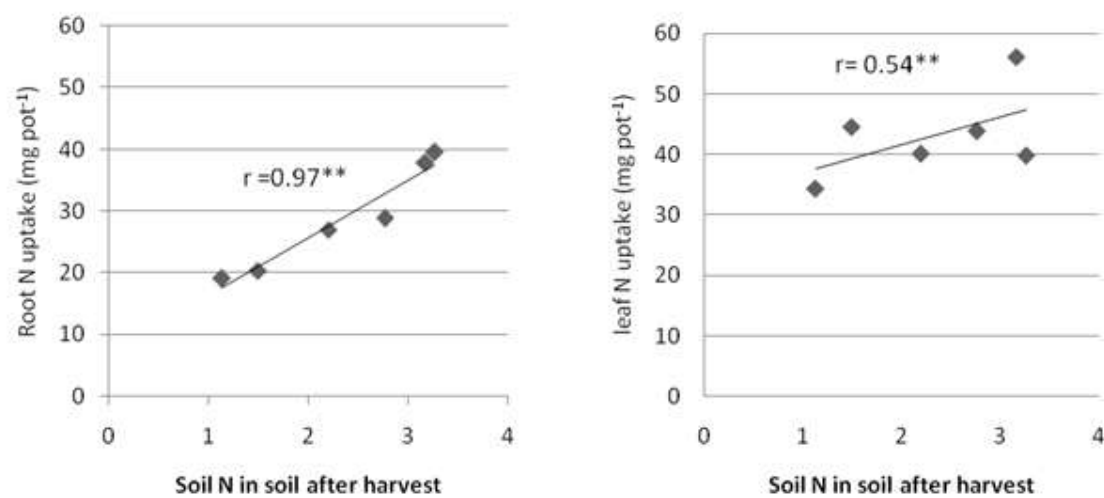

${ }^{* *}$ Correlation is significant at the 0.01 level, ${ }^{*}$ Correlation is significant at the 0.05 level.

Fig. 5. Relationship between radishes leaf and $\operatorname{root} \mathbf{N}$ uptake and soil $\mathbf{N}$ after harvest

Egypt. J. Soil Sci. 56, No. 2 (2016) 
Correlations between radish plant $N$ uptake and soil count of anaerobic $\mathrm{N}_{2}$ fixing bacteria after harvest

At the end of the experiment, leaf and root of radish showed a significant negative correlation between $\mathrm{N}$-uptake and soil counts of anaerobic $\mathrm{N}_{2}$ fixing bacterial counts (Fig. 6). Results of that $\mathrm{N}$ mineralized increased with soil counts of anaerobic $\mathrm{N}_{2}$ fixing bacterial content; these results emphasis the results reported by Antonopoulos (1999).
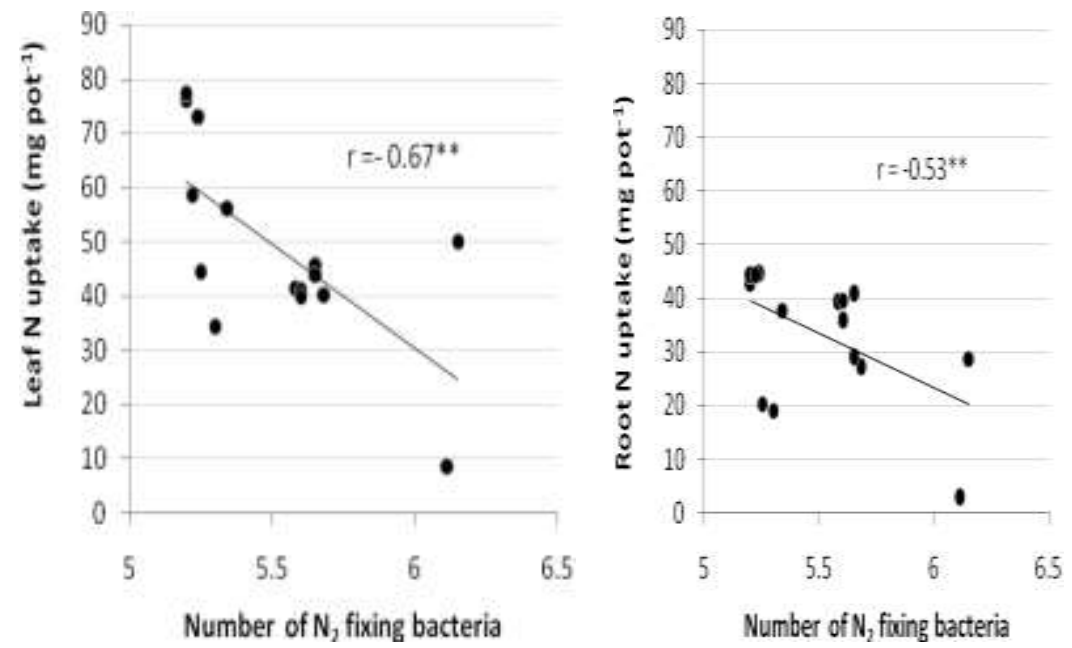

** Correlation is significant at the 0.01 level, ${ }^{*}$ Correlation is significant at the 0.05 level.

Fig. 6. Relationships between radishes leaf and root $N$ uptake and soil count of anaerobic $\mathbf{N}_{2}$ fixing bacteria after harvest

\section{Conclusions}

The use of compost tea and $\mathrm{N}_{100}$ produced maximum yield as well as $\mathrm{N}, \mathrm{P}$ and $\mathrm{K}$ uptakes by radish plants. CT2 (molasses + ammonium sulphate) $+\mathrm{N}_{50}$ showed lower nutrient uptakes of N, P and K uptake and lower soil N, P and K content after harvest. This suggests that ammonium sulphate added to compost tea may enhance residual effect. The integrated application of organic and inorganic fertilizers not only increases the availability of nutrients, but also improves soil fertility. After harvest, a highly significant negative correlation was found between leaf and root $\mathrm{N}$ uptake and the number of $\mathrm{N}_{2}$ fixing bacteria. Therefore, compost tea is considered as an important organic source for enhancing nutrient availability by plant, soil and soil microorganisms.

\section{References}

Abd-El-Malek, Y. (1971) Free-living nitrogen-fixing bacteria in Egyptian soil and their possible contribution to soil fertility. Plant and Soil, 35 (1), 423-442.

Egypt. J. Soil Sci. 56, No. 2 (2016) 
Angers, D.A., Chantingny, M.H., Macdonald, J. D., Rochette, P. and Côte, D. (2010) Differential retention of carbon, nitrogen and phosphorus in grassland soil profiles with long-term manure application. Nutr. Cycl. Agroecosys, 86, 225-229.

Antolan, M.C., Pascual, I., Garcaa, C., Polo, A. and Ajnchez, S. (2005) Growth, yield and solute content of barley in soils treated with sewage sludge under semiarid Mediterranean conditions. Field Crops Res. 94, 224-237.

Antonio, G.F., Carlos, C.R., Reiner, R.R., Miguel, A.A., Angela, O. L. M. Cruz, M.J.G. and Dendooven, L. (2008) Formulation of a liquid fertilizer for sorghum (Sorghum bicolour (L.) Moench) using vermicompost leachate. Bioresour. Technol. 99, 6174-6180.

Antonopoilos, V.Z. (1999) Comparison of different models to simulate soil temperature and moisture effects on nitrogen mineralization in the soil. J. Plant Nutr. Soil Sci., 162, 667- 675.

Atlas, R.M. (2005) Handbook of Media for Environmental Microbiology (Second ed.) Taylor and Francis- gp. CRC Press NY. USA.

Aulakh, M.S., Khera, T.S. and Doran, J.W. (2000) Mineralization and identification in upland, nearly saturated and flooded subtropical soil. II. Effect of organic manures varying in N content and C: N ratio. Biol. Fertil. Soils, 31, 168-174.

Aziz, Z.A., Davey, M.R., Power, J.B., Anthony, P., Smith, R.M. and Lowe, K. C (2007) Production of asiaticoside and madecassoside in Centella asiatica in vitro and in vivo. Biol. Plant, 51, 34-42.

Bernal-Vicente, A., Ros, M., Tittarelli, F., Intrigliolo, F. and Pascual, J. A. (2008) Citrus compost and its water extract for cultivation of melon plants in greenhouse nurseries. Evaluation of nutriactive and biocontrol effects. Biores. Technol. 99, 8722-8728.

Bess, V.H. (2000) Understanding compost tea. BioCycle, 41, 71-72.

Bourn, D. and Prescott, J. (2002) A comparison of the nutritional value, sensory qualities, and food safety of organically and conventionally produced foods. Crit. Rev. Food Sci Nutr. 42(1), 1-34.

Brunner, P. H. and Wasmer, H.R. (1978) Methods of analysis of sewage sludge solid wastes and compost. WHO International Reference Center for Wastes Disposal $(\mathrm{H}-$ 8600), Dulendrof Switzerland.

Carpenter-Boggs L. (2005) Understanding the science: diving into compost tea BioCycle, 46 (7), 61-62.

Cassman, K.G. and Munns, D. M. (1980) Nitrogen mineralization as affected by soil moisture, temperature and depth. Soil Sci. Soc. Am. J. (44), 1233-1237.

Conn, K.L. and Leci, E. (1998) A quantitative method for determining soil populations of streptomyces and differentiating potential potato scab-inducing strains. Plant Dis. 82, 631-638.

Egypt. J. Soil Sci. 56, No. 2 (2016) 
Cottenie, A., Verloo, M., Kickens, L., Velghe, G. and Camerynch, R. (1982) Chemical analysis of plants and soils. Laboratory of analytical and Agrochemistry, State Univ., Ghent, Belgium.

Craft, C.M. and Nelson, E.B. (1996) Microbial properties of composts that suppress damping-off and root rot of creeping bentgrass caused by Pythium graminicola. Appl. and Environ. Microbiol. 62, 1550-1557.

Danon, M., Zmora-Nahum, S., Chen, Y. and Hadar, Y. (2007) Prolonged compost curing reduces suppression of Sclerotium rolfsii. Soil Biol. \& Biochem., 39, 19361946.

Daugaard, H (2001) Nutritional status of strawberry cultivars in organic production. $J$. PlantNutr. 24, 1337-1346.

Difco, M. (1985) Dehydrated Culture Media and Reagents For Microbiology. $10^{\text {th }}$ ed. Difco laboratories, Detroit Michigan USA.

Dubeikovsky, A. N., Mordukhova, E. A. Kochetkov, V.V. Polikarpova, F. Y. and Boronin, A. M. (1993) Growth promotion of blackcurrant softwood cuttings by recombinant strain Pseudomonasfluorescens BSP53a synthesizing an increased amount of indole-3-acetic acid. Soil Biol. Biochem. 25, 1277-1281.

Ebid, A., Uneo, H. and Ghoneim, A. (2007) Nitrogen mineralization kinetics availability in soil amended with composted tea leaf, coffee waste and kitchen garbage. Int. J. Soil Sci. 2, 96 - 106.

Edris, A.E., Shalaby, A. and Fadel, H.M. (2003) Effect of organic agriculture practices on the volatile aroma components of some essential oil plants growing in Egypt. 11: sweet marjoram (Origanum marijorana L.) essential oil. Flavour and Fragr. J. 18, 345-351.

Elsherbeny, E.S., Hendawy, A.A., Youssef, N.Y. and Hussein, M.S. (2012) Response of turnip (Brassica rapa) plants to Minerals or Organic Fertilizers Treatments. J. Applied Sci. Res. 8 (2), 628-634.

Fuller, R., Norton, J., Feber, L.R., Johnson, R.E., Chamberlain, P.J., Joys, A.C., Mathews, F., Stuart, R.C., Townsend, M.C., Manley, W.J., Wolfe, M.S., Macdonald, D.W. and Firbank, L.G. (2005) Benefits of organic farming to biodiversity vary among taxa. Biol. Lett. 1, 431-434.

Gagnon, B., Lalande, R. and Fahmy, S.H. (2001) Organic matter and aggregation in a degraded potato soil as affected by raw and composted pulp residue. Bio. Fertil. Soil. 34, 441-447.

Ha, K.V., Marschner, P. and Bunemann, E.K. (2008) Dynamics of C, N, P and microbial community composition in particulate soil organic matter during residue decomposition. Pl. Soil, 303, 253-264.

Hargreaves, J.C., Adl, M. S. and Warman, P. R. (2008) The effects of municipal solid waste compost ansd compost tea on mineral element uptake and fruit quality of strawberries. Compost Sci. Utilization, (17), 85 - 94.

Egypt. J. Soil Sci. 56, No. 2 (2016) 
He, X., Logan, T.J. and Traina, S. J. (1995) Physical and chemical characteristics of selected U.S. municipal solid waste composts. J. Envrion. Qual. 24, 543-552

Heather, M.D., Alexandra, G.S. and Richard, P.D. (2006) Compost and manure mediated impacts on soilborne pathogens and soil quality. Soil Sci. Soci. Amer. J., 70, 347-358.

Hegazy, M. I., Ali, A. S. and Abbas, E. A. (2013) Evaluation of compost and compost extract efficiency as bio-control agents on damping-off disease incidence of fenugreek (Trigonella foenum-greacum). Zagazig J. Agric. Res. 40 (2), 239-249.

Herman, R. P., Provencio, K.R. Torrez, R. J. and Seager, G. M. (1993) Effect of water and nitrogen additions on free-living nitrogen fixer population in desert grass root zone. Appl. Environ. Micro. 59, 3021-3026.

Hirzel, J., Cerda, Millas, F. and France, P. (2012) A compost tea effects on production and extraction of nitrogen in ryegrass cultivated on soil amended with commercial compost. Compost Sci. \& Util, 20, 97-104.

Ingham, E.R. (2005) The Compost Tea Brewing Manual, $5^{\text {th }}$ ed. US Printings, Soil Foodweb Inc, Oregon.

Kavroulakis, N.C., Ntougias, S., Zervakis, G.I. and Papadopou, K.K. (2005) Local and systemic resistance against fungal pathogens of tomato plants elicited by compost derived from agricultural residues. Physiol. Mol. Plant Pathol. 66, 163-174.

Klute, A. (1986) Methods of Soil Analysis (second ed.) American Society of Agronomy, Inc. Soil Science Society of America. Madison, Wisconsin. USA.

Loveland, P. and Webb, J. (2003) Is there a critical level of organic matter in the agricultural soils of temperate regions? a review. Soil Till. Res. 70, 1-18.

Martyniuk, S., Stachyra, A. and Gajda, A. (2002) Long-lasting beneficial effects of slurry application on some microbial and biochemical characteristics of soil. Pol. J. Environ. Stud. 11, 727-730.

Naidu, Y., Meon, S., Kadir, J. and Siddiqui, Y. (2010) Microbial starter for the enhancement of biological activity of compost tea. Int. J. Agric. Biol. 12, 51-56.

National Organic Standards Board (NOSB) USA (2004) Compost tea task force report.http://www.ams.usda.gov/nosb/meetings/CompostTeaTaskForceFinalReport.p df.Cited 24 Aug. 2007

Nelson, E.B. and Boehm, M.J. (2002) Microbial mechanics of compost- induced disease suppression. Biocycle, Part II, 43, 51-55.

Otten, L. (2001) Wet-dry composting of organic municipal solid waste: current status in Canada. Can. J. Civ. Eng. 28 (Supplied) 124-130.

Page, A.L., Miller, R. H. and Keeny, D.R. (Ed.) (1982) Methods of Soil Analysis, Part 2 Chemical and Biological Properties. American Society of Agronomy Inc. Mascson, Wisconsin USA.

Egypt. J. Soil Sci. 56, No. 2 (2016) 
Pant, A.P., Radovich, T. J. K., Hue, N.V., Talcott, S.T. and Krenek, K.A. (2009) Vermicompost extracts influence on growth, mineral nutrients, phytonutrients and antioxidant activity in pak choi (Brassica rapa $\mathrm{cv}$. Bonsai, Chinensis group) grown under vermin-compost and chemical fertilizer. J. Sci. Food Agric. 89, 2383-2392.

Schröder, J.J., Jansen, A.G. and Hilhorst, G.J. (2005) Long-term nitrogen supply from cattle slurry. Soil Use Manage. 21, 196-204.

Siddiqui, Y., Islam, T.M., Naidu, Y. and Meon, S. (2011) The conjunctive use of compost tea and inorganic fertilizer on the growth, yield and terpenoid content of Centella asiatica (L.) urban. Scientia Horticulturae, 130, 289 - 295.

Siddiqui, Y., Meon, S., Ismail, R., Rahmani, M. and Ali, A. (2008) Bio-efficiency of compost extracts on the wet rot incidence, morphological and physiological growth of okra (Abelmoschus esculentus [(L.) Moench]). Sci. Horti. 117, 9-14.

Sifola, M.I. and Barbieri, G. (2006) Growth, yield and essential oil content of three cultivars of basil grown under different levels of nitrogen in the field. Sci. Horti. 108, 408-413.

Soltanpour, P. N. and Schwab, A. P. (1977) A new soil test for simultaneous extraction of macro and micronutrients in alkaline soils. Commun. Soil Sci. Plant Anal. 3, 195207.

Streeter, J. G. (1988) Inhibition of legume nodule formation and $\mathrm{N}_{2}$ fixation by nitrate. CRC Crit. Rev. Plant Sci. 7, 1-23.

Sylvia, E.W. (2004) The effect of compost extract on the yield of strawberries and severity of Botrytis cinerea. J. Sustainable Agric. 25, 120-129.

Takenaka, S., Sekiguchi, H., Nakaho, K., Tojo, M., Masunaka, A. and Takahashi, H. (2008) Colonization of Pythium oligandrum in the tomato rhizosphere for biological control of bacterial wilt disease analyzed by real-time PCR and confocal laserscanning microscopy. Phyt. 98, 187-195.

Warman, P. R. (2005) Soil fertility, yield and nutrient contents of vegetable crops after 12 years of compost or fertilizer amendments. Biol. Agric. Hort. 23, 85-96

Winter, C. K. and Davis, S. F. (2006) Organic Foods. J. Food. Sci. 71(9), 117-124. 


\title{
الآثار المترتبة على الإستخدام المشترك لشاي الكومبوست والسماد

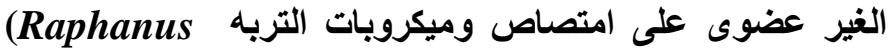 Sativus)
}

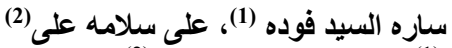

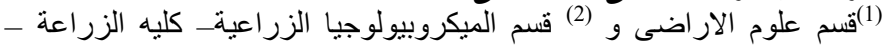

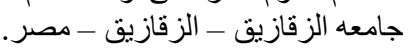

إضافه الأسمدة العضويه للتربه تعتبر من الإستبر اتيجيات الهامه لزياده خصوبه

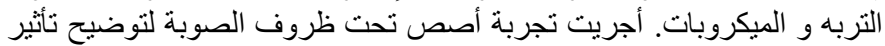

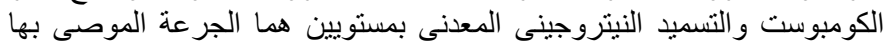

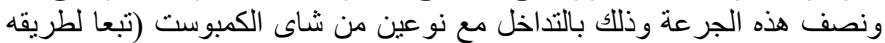

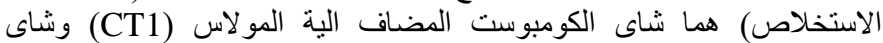

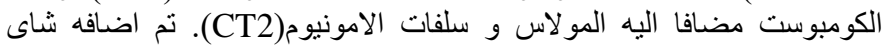

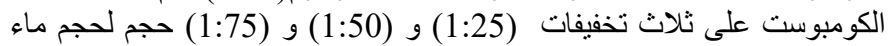

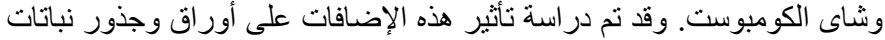

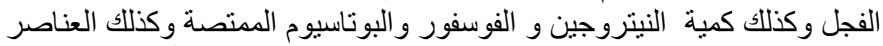

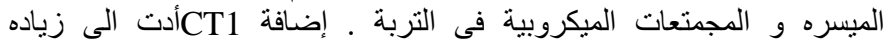

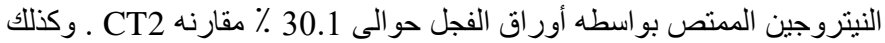

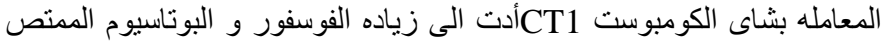

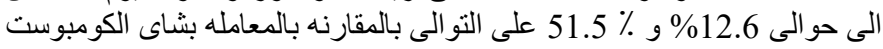
CT2

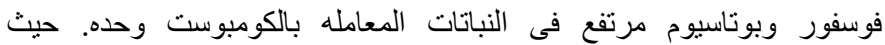

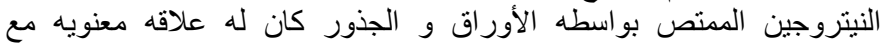

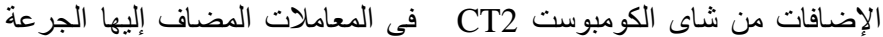

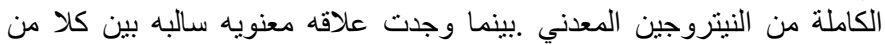

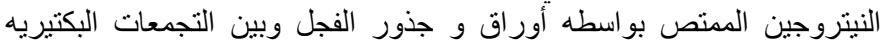
المثبته للنيتروجين في التربنه بعد الحصنه أوراد. 